UDC 005.93:005.21-025.13

DOI: 10.15673/fie.v11i3.1461

Kalaman 0 .

Ph. D., Associate Professor

Department of Management and Logistics

E-mail: kalaman.olga@gmail.com

ORCID ID: 0000-0001-5586-7654
Savenko I.

Doctor of Economics, Professor

Department of Management and Logistics

E-mail: kaf-ml@gmail.com

ORCID ID: 0000-0008-5217-1478

\author{
Dolynska 0. \\ Assistant \\ Department of Marketing, Business and Trade \\ Odessa National Academy of Food Technologies \\ Kanatna str., 112, Odesa, Ukraine, 65039 \\ E-mail: dolinskaya_alena@ukr.net
}

\title{
CONCEPTUAL POSITIONS OF ENTERPRISE STRATEGY FUNCTIONING
}

Ensuring the effective development of manufacturing enterprises requires a number of activities that are concerned with the planning and systematic organization of its activities, making and implementing management decisions, conducting production and innovation processes and evaluating the results achieved on the basis of the involvement of internal and external strategic impulses.

The article analyzes the concept of strategy, its structure and its functions. It has been revealed that the task of strategic planning of activity and development of the enterprise is one of the important in the conditions of competition. Many real enterprises were not prepared for its decision. In order to understand this process, it is necessary to disclose the content of the strategic approach in enterprise theory and in the practice of enterprise management. The main objective of this article is to determine the requirements for the development and implementation of strategies arising from the theoretical analysis of the internal and external environment of the enterprise. In formulating the strategy of the enterprise it is important not to get lost in the infinity of incomparable possibilities of strategic choice, to reduce the variety of these opportunities in each line of activity of the enterprise to a discrete set of options. Developing and presenting recommendations for conducting this necessary part of strategy development and implementation is the second objective of this article.

Key words: enterprise strategy, strategic management system, strategic decisions, enterprise policy, sections of strategy, strategic planning, role of strategy.

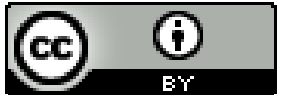

This work is licensed under a Creative Comm
http://creativecommons.org/licenses/by/4.0/
Statement of the problem and its connection with important scientific and practical tasks. The tasks of strategic planning of activity and successful enterprise development is one of the most important in the competition conditions. Unfortunately, many domestic enterprises were not prepared for its decision. This is explained by the lack of elaboration of strategic theory and methodology, both suitable for implementation at domestic enterprises and taking into account the achievements of the world economic and modern management theory.

The analysis of the latest publications on the problems. There are a number of approaches to formulating a strategy based on corporate, interactive, intuitive and chaotic planning. The problems of strategy development and implementation are considered in their research by O. P. Gradov [1], A. A. Thompson and A. J. Strickland [5], Wright P., Pringle C., Kroll M. [6], K. Andrews and K. Christensen [24], I. Ansoff [23] and others. However, questions about the conceptual positions of the enterprise strategy functioning and the strategy functions still remain unresolved.

Forming of the aims of the research. In order to understand this process, it is necessary to disclose the content of the strategic approach in enterprise theory and in the practice of enterprise management. The main objective of this article is to determine the requirements for the development and implementation of strategies arising from the theoretical analysis of the internal and external environment of the enterprise. In formulating the strategy of the enterprise it is important not to get lost in the infinity of incomparable possibilities of strategic choice, to reduce the variety of these opportunities in each line of activity of the enterprise to a discrete set of options. Developing and presenting recommendations for conducting this necessary part of strategy development and implementation is the second objective of this article.

Giving an account of the main results and their substantiation. Let's start with explaining the meaning of the basic term "strategy". Despite the large amount of educational and scientific contemporary litera- 
ture on strategic planning at the micro level, a clear, precise and clear definition of the concept of "strategy" and its place in an orderly system of enterprise functioning has not been determined. Yes, prof. A.P. Gradov views strategy as a way to achieve the specific goals of the production system [1]. Also, the economic strategy is recommended to understand "a dynamic system of interconnected rules and practices, which ensures the effective formation and maintenance in the long run of competitive advantages of the firm in the internal and external markets of individual and public goods" [2].

Thus, the essential emphasis is shifted to the "rules and practices" system, and the target aspect is related to the firm's competitiveness. Regarding the rules and techniques, it would be worth clarifying the nature of these rules, because not all rules (institutions) are strategic. As for the competitiveness of the enterprise, this concept also needs to be defined. In a literal sense, the competitiveness of an enterprise is a combination of its features and capabilities that enable it to win in the market with other agents. But using this concept, we shift the focus to an important area of enterprise functioning - the fight against other agents. However, the company may not be in a competitive state, but simply try to fulfill the order and find itself unable to execute it at the proper level. Competition is just one of the types of market relations. The relationship between the consumer and the supplier is equally important. It is important that an enterprise can be a monopolist, but this is not a guarantee that its strategic problems are solved [3, 4].

In the book by A. A. Thompson, A. J. Strickland, strategy is initially defined as "a plan for managing a firm aimed at strengthening its position, customer satisfaction and achieving its goals," and, ultimately, it is interpreted as a set of specific rules for strategic decision making. which guides the organization in its further activities [5].

According to Peter Wright, Charles Pringle and Mark Kroll, strategy is a long-term, well-defined direction of the organization's development in the sphere of its activity, means and types of its activity, systems of relations in it, as well as the position of the organization in the external environment, which leads to the achievement of its goals. Many researchers point to the strategy, as a qualitative sequence of actions and existence used by an enterprise to achieve its goals [6].

Another kind of connection between strategy and goals is emphasized by J. Mokler, saying that enterprise strategies are long-term goals and plans that are formulated to ensure effective interaction of the enterprise with its competitive environment [7].

A more detailed definition, which corresponds more to understanding strategy as a model than as a plan, is shown in V. S. Efremov's work. He notes that business strategy is always a way of action, which determines the well-defined and to some extent sustainable direction of production and commercial behavior of the organization over a rather long historical interval. This type of action is distinguished within a set of principles, rules and priorities that are determined by the circumstances of the place, time, cause, technique and method of action. In such definitions, we can note the commonality with the notion of routines as inherited "normal and predictable patterns of behavior of firms" [8].

G. Mintzberg, B. Alstrend and D. Lampel, basing on linguistic analysis and case classification of strategy concepts, propose a "five-layer" definition of strategy: strategy is a plan that combines the description of the enterprise's goals in the form of market prospects position and internal status, as well as the principles of behaviour that the company adheres to in pursuit of these goals [9].

It is important to note that a system of strategic management (management) is considered a system of enterprise management, which is based on timely strategic planning, which is complemented by reconciling current decisions with strategic ones along with adjusting and controlling the implementation of this strategy [10].

Strategic planning differs from the well-known long-term planning in the former USSR by two main features (we exclude from consideration differences in the nature of enterprise functioning in a centralized and market economy): differences in the "horizon" and in the subject of planning. The horizon of a long-term plan is clearly defined before its formation, while the enterprise's strategy is formed indefinitely. Its duration depends on the state of the environment or on the occurrence of some internal events that change the strategic circumstances of the enterprise. The term strategic planning can be conditionally defined as "comprehensive", bearing in mind that the appearance of unaccounted changes in the levels of strategic factors before necessitates a revision of the strategy [11].

In the content (subject matter), strategic planning is based only on basic processes within and outside the enterprise, paying attention not only to the notable results of the enterprise as an end in itself, but to increasing of its socio-economic future potential [12].

Finally, the enterprise strategy differs significantly from the concept of "enterprise policy". The enterprise policy defines the general directions of its activity. It aims at target management decision-making in the enterprise in a defined strategy direction, at portraying the future of the enterprise for its partners, stakeholders and investors. Policy should be based on strategy. Therefore, the concept of "strategy" is more capacious and fundamental than the concept of "politics". According to the content presented earlier, the strategy covers the decisions in each relatively independent area of the enterprise. First of all, these are the areas of managing the structure and volume of production, the behavior of enterprises in the market of goods, as well as the strategic aspects of internal management of the enterprise, etc. [13].

It is important to note that a successful enterprise strategy should include the following sections that are relevant to the areas of activity of the enterprise.

1. Commodity market - defines the nomenclature, precisely defined volume and conditioned quality of products (goods, services) produced and the behavior of the enterprise in the commodity market.

2. Resource-market - determines the behavior of the enterprise in the market of production and financial factors and certain resources of production. 
3. Technological - determines the dynamics of technology used by the enterprise and the impact of factors acting on the market on it.

4. Integration - defines the integration functional and managerial interactions of enterprises with each other.

5. Financial and investment - defines ways to attract, accumulate and spend important financial resources for the enterprise.

6. Personnel - defines the type and structure of the collective of employees at the enterprise and their interaction with the shareholders [14].

According to the results of the systemintegration intentionally-eventualized theory of the enterprise, five further sections should be added to these sections.

7. Corporate culture formation strategy (cultural strategy).

8. The strategy of forming the internal institutional environment and managing its interaction with the external institutional environment (institutional strategy).

9. Strategy for acquisition, creation, accumulation and storage of knowledge (cognitive strategy).

10. The strategy of managing the processes of imitation of the behavior of other companies and their own behavior (imitation strategy).

11. Event management strategy (possible strategy).

These sections of the strategy correspond to the concepts of cultural management, institutional, cognitive, imitative and eventual management as components of strategic management as a whole.

Enterprise management as an independent activity should be reflected in the integrated enterprise strategy.

12. Management strategy - defines the nature of enterprise management when implementing a certain chosen strategy.

Finally, an additional (and last) section of a comprehensive enterprise strategy may be a section on enterprise restructuring. According to the survey, nearly two out of every three companies have either been restructured or are undergoing restructuring. We consider it appropriate to allocate an independent section of the strategy for this line of activity.

13. The restructuring strategy is to bring the structure (production-technological and organizationalmanagerial) in line with the changed conditions and strategy of operation [15].

Commodity-market, resource-market, technological, financial-investment and personnel strategies refer mainly to the functioning of the main subsystem of the enterprise, which directly produces commodity products. Cultural, institutional, cognitive strategies determine the functioning of the respective subsystems.

Integration strategy and tactics of enterprise management are studied as the opposite direction: the integration strategy is characterized by an "inside-out" view. On the contrary, the management strategy is characterized by a perspective: "from the inside" (from external tasks and installations to their implementation by subsystems within the enterprise) [16].
With regard to mental strategy, since the mental level of employees of a company is difficult to pursue purposeful action, we mean including this topic in the cultural strategy section as well as in the personnel strategy section (in terms of hiring and firing).

The unification into one section of all types of imitation decisions made in a particular situation at this or other enterprises is due to the similarity of borrowing procedures. Although the sources of information here are different: in the case of the simulation subsystem, it is a question of benchmarking, while in the historical subsystem, the main thing is to analyze the company's own history. That is, on the one hand, all subsystems of the enterprise were reflected in the strategy and, on the other, all sections of the strategy were assigned to either a subsystem of the enterprise or the whole enterprise as a whole.

I would like to emphasize the particular importance of formulating and implementing a possible strategy. In companies with regular strategic management or formation, it is advisable, within the unit responsible for strategic planning (management), to create a special group of "eventmakers", ie persons who plan and "create" events that turn the selected facts into events [17].

Now, by clarifying the concept and structure of enterprise strategy, let us focus on some important aspects of the role of strategy in the life of the enterprise. This role, as shown by studies of leading firms in developed foreign countries, is quite significant and can be characterized as follows.

1. Strategy as an attainable ideal.

The main objective of the strategy is to reflect the prospects of the company development. For Ukrainian companies, perspective is of particular importance. Due to a number of historical reasons, the peculiarities of the nano-economic environment of functioning of enterprises, the domestic worker feels an urgent need to involve not only the labor collective today but also the future company. Companies without a future is not an attractive place of work for most. But a company without a strategy is largely a company with no future. The strategy serves as an indispensable means of acquiring a specific and unique way of perceiving the world, the paradigm of doing business, belonging to the corporate culture by employees and managers of the company.

The attainment of such a state by the enterprise and the position in the economic environment, which is embodied in the strategy are very important. This reach is ensured by the connectedness of the past and the future, which must be implemented in the strategy. Successful strategic configurations are increasingly incorporating components that characterize the transition from the past to the future. This is different from the transition from "present to future", in which the future is the result of free choice and reaction of the environment. In formulating the strategy, the system of mutual expectations must be organically combined with the system of interests of the subjects and the system of their intentions (intentional system) [18].

Many Western theorists believe that in a changing external environment, introverted, bureaucratic, 
and self-centered corporate culture norms are capable of generating corporate crises. Instead of outdated recommendations like "business is a business that regulates the internal component of business in order to succeed", appeals have become widespread called to look beyond the current time and look beyond the business of the company in space.

2. Strategy as an integrator.

The process of developing and implementing a strategy serves as a powerful integrating factor during which the following things are integrated:

a) interests of actors involved in the process of strategy development and implementation;

b) functions of units of the enterprise;

c) flows of material, financial and information resources;

d) flows of system events;

e) elements of intellectual capital - between themselves and with tangible assets;

e) functional subsystems, representing the system structure of the enterprise.

An important role is played by the formation of the enterprise strategy in such a process as the effective use of the abilities and talents of employees. The strategic process not only allows to identify these talents, but also facilitates their inclusion in production and economic activity. The consolidation role of strategy at the enterprise can practically not be replaced by anything [19].

3. Strategy as an object (sample) for imitation.

This is a retrospective review of a strategy that has been developed previously and the results of its implementation. The result of such actions is a sample strategy similar to the product samples displayed in the showroom. This algorithm will be used in the future to formulate strategies that take into account changing conditions under the company's historical subsystem. In addition, the analytic strategy determines to some extent the image and reputation of the enterprise.

A list of such strategy algorithms (such as commodity-market) is widely known from successful company stories, starting with an example that reflects G. Ford's philosophy: "Any color (of a car) is suitable to be black."We'll end with an example that reflects increased attention to market response: improved quality, differentiation and price competition; the need for innovation and the speed of change. In a certain sense, this is the most important concept of the strategy, because it is actually implemented, integrates the results of the enterprise's activities to achieve all plans and actions, as well as all the environmental responses to these actions [20].

Strategy as an algorithm appears in the form of a hierarchical set of more detailed developments: from superficial description to detailed regulations.

4. Strategy as a response to external challenges.

In the modern period of frequent and unexpected changes, an organizational and functional subsystem within the enterprise is needed, which should realize the search, fixation and comprehension of the strategic problems of the enterprise as they manifest and develop. Thus, the strategy becomes one of the in-house mechanisms that continuously provide relevant answers to strategic problems and "challenges". The problems that emerge form the "strategic agenda" of enterprises - they need to be studied and we should find an effective strategic answer. Such a system corresponds to competent strategic management and provides an adequate approach to the formation of programs for its development. Relying on a strategy can significantly reduce the costs of making dayto-day decisions for your business.

\section{Strategy as a power.}

In this aspect, the strategy is the result of interaction between all interested parties in the production, which gives, as a rule, extended powers to those who develop and manage the implementation of this strategy. In the world of information networks of the last decade there is a situation in which the power, distributed among a large number of people, events and other phenomena, can unexpectedly appear anywhere in the interdependent network external environment and affect the internal development of the company. Situations where other, equally powerful, centers of power unexpectedly emerge require a response either in the form of a "political agreement" or in the form of strategic planning. The properly designed, discussed and adopted strategy must become a real power in the sense that even the highest official in the company and the "majority" owner will not be able to break it without proper review.

When developing a strategy, one must consider the possibility of manifesting certain administrativepolitical and / or criminal situations in the interests of the enterprise. The distribution of power inside and outside the enterprise is dynamic and should be the subject of particular attention when developing a strategy. The movement towards the creation of corporate crisis prevention systems must begin with the active and systematic interventionism of the enterprise into an external environment filled with scattered elements of market and administrative power.

6. Strategy as a competitive position of the enterprise.

Leading competitive strategy theorists, including M. Porter, identify the main objectives of the management strategy as selecting and supporting the "winning" position of the market environment. According to positioning theory, the key to strategic success is to obtain an excess of average return on investment through the development and implementation of competitive strategies [21].

The concept of M. Porter shows that the "political" and "competitive" aspects of the situation of the enterprise are often very close to each other. In the situation where the enterprise has significant competitive power, for example, in a monopolistic situation, it is possible to ignore aspects of the external environment and focus on creating effective management structures, production and planning [21].

The gradual complication of the external environment leads o a challenge of the fundamental role of competition in the society. The market appears as a complex system, in which the relations of elements (economic entities) are based on coordination (cooperation in the implementation of specific projects) and co-evolution 
(concerted development) to the same degree as on competition. This is a matter for those who see significant dangers for businesses in approaching the crisis by enhancing competitiveness. of personnel.

7. Strategy as a system of motivation and control

It emphasizes the role of strategy in the consolidation and motivation of the team and each employee and manager separately. It is important when developing the strategy to strike a balance between evolutionary change in the enterprise, revolutionary change, and conservative development that retains the positive features of the organization. In some cases, these types of dynamics are concentrated in specific parts of the organization, enabling employees to find the areas of activity and teams that best meet personal innovation priorities [22].

In the essence, the strategy plays the role of minimizing administrative and transaction costs, as it saves money spent in the absence of a strategy to find and analyze operational solutions, including reducing transaction costs when selecting contractors of the enterprise.

8. Strategy as a means of ensuring the integrity of the enterprise.

Summarizing some of the findings, it should be emphasized that the problem of enterprise integrity is one of the most pressing problems in the post-restructuring economy. During the recession, enterprises lost many structural elements related to investment and innovation circuits. Management has lost its focus, and the internal space of the company has acquired the properties of fragmentation. The Strategic Planning Institute is a reliable tool to counteract these trends. This is due both to the knowledge of the possible future, carried out during the development and implementation of the strategy, and to the manifestation of the organizing power of the strategy. In fact, strategy represents one of the expressions of the "soul" of the enterprise, and by organizing a strategic process at the enterprise, we thereby strengthen and refine the "soul" of the enterprise [26].

Conclusions and prospects of the further investigations. As the practice has shown, an enterprise must implement several strategies at the same time. Even very similar in their development and activity, enterprises can apply different strategies and get excellent economic results. In addition to combining these strategies and areas, there may be some consistency in the implementation of the strategies. This is usually called a combined strategy. Such strategies are the key to the success of virtually any enterprise.

Currently, there is no comprehensive system for evaluating the enterprise development strategy. There is no clear theoretical position on its principles - such as systematicity, complexity, objectivity, dynamism, continuity, optimality and constructiveness.

Insufficient elaboration of the strategic planning process, unpreparedness of managers of different levels to make informed and balanced decisions leads to such phenomena as the breakdown of economic ties, failure to fulfill contractual obligations, mutual non-payment, reduction of investment activity and, most importantly, of STP pase. In most enterprises, a number of problems requiring strategic response remain unattended by executives, while the decision-making system requires a greater role for the strategic component. The quality of strategic decisions is a determining factor in realizing the potential of enterprises and the efficient use of resources.

Thus, to account for modern economic realities, the process of forming an enterprise development strategy must be based on the theoretical and methodological principles outlined above, and be supplemented by a new mechanism that increases the systematicity of strategic decisions made and increases the ability to algorithmize the processes of certain stages of strategy formation and provision.

The review of the above mentioned features made it possible to conclude that it is advisable to develop the concept of forming a strategy for the development of a modern enterprise in the conditions of increasing the scientific intensity of its production, which should provide the basic mechanism of the process of formation of the system of priority goals of the enterprise with their further harmonization with the innovation of development. Accordingly, the key notion of this concept should be the essence of enterprise development strategy, which:

- means the set of its main goals related to the qualitative updating of the key activities of the enterprise and the main ways to achieve these goals;

- identifies the main stages of the process of forming an enterprise development strategy, taking into account the innovative choice of development strategy;

- acknowledges that the formation and maintenance of a strategy for the development of a machinebuilding enterprise are not identical concepts.

\section{References}

1. Hradov, O. P. (1995). Ekonomichna stratehiia firmy : pidruchnyk [The firm's economic strategy]. SPb: Fakhova literatura.

2. Hradov, O. P., Hlukhov, V. V., Hrihorev, Yu. P., \& Didenko, N. I. (2003). Ekonomichna stratehiia firmy : navchalnyi posibnyk [The firm's economic strategy]. SPb: Fakhova literatura.

3. Stupnytska, T., Kalaman, O., \& Markova, T. (2019). Ensuring of the enterprise operation effacacy: Management aspect. Periodicals of Engineering and Natural Sciences, 7(2), 534-545.

4. Kuprina, N., Stupnytska, T., Vaskovska, K., Boyko, O., Baraniuk, Kh., \& Markova, T. (2019). Managing the Competitiveness of the Enterprise in the Context of Transformational Change. International Journal of Recent Technology and Engineering, 8(2), 4909-4914. doi: 10.35940/ijrte.B3706.078219

5. Tompson, A. A. \& Striklend, A. D. (2006). Stratehichnyi menedzhment: kontseptsii i sytuatsii dlia analizu [Strategic management: concepts and situations for analysis]. M: Viliams. and Bacon.

6. Wright, P. L., Pringle, C. D., \& Kroll, M. J. (1992). Strategic management : text and cases. Boston: Allyn

7. Mockler, R. J. (1992). Strategic Management: An Integrative Context-Specific Process. Harrisburg-London: Idea Group Publishing. 
8. Yefremov, V. S. (1998). Stratehiia biznesu: Kontseptsii i metody planuvannia [Business Strategy: Planning Concepts and Methods]. M.: Finpress.

9. Mintsberh, H., Alstrend, B., \& Lempel, D. (2000). Shkoly stratehii [School Strategies]. SPb: Piter.

10. Zybareva, O., Verbivska, L., Lopashchuk, I., Kalaman, O., Derkach, T., \& Smentyna, N. (2019). Strategically-Oriented Enterprise Management through Information Systems. International Journal of Recent Technology and Engineering, 8(2), 3014-3017. doi: 10.35940/ijrte.B2900.078219

11. Bondarenko, S., Liganenko, I., Kalaman, O., \& Niekrasova, L. (2018) Comparison of Methods For Determining The Competitiveness of Enterprises To Determine MarketStrategy. International Journal of Civil Engineering and Technology, 13(9), 890-898.

12. Aheieva, I. M., \& Aharkova, O. V. (2018) Doslidzhennia pidkhodiv do formuvannia stratehichnykh napriamiv rozvytku pidpryiemstv Pivdennoho rehionu [Research of approaches to formation of strategic directions of development of the enterprises of the Southern region]. Proceedings from MIIM '12: VI Mizhnarodna naukovopraktychna konferentsiia "Ekonomichni ta sotsialni aspekty rozvytku Ukrainy na pochatku XXI stolittia" - The Sixth International Scientific and Practical Conference "Economic and social aspects of Ukraine's development at the beginning of the 21st century». (pp. 65-67). Odesa: ONAKhT.

13. Kalaman, O., Volodina, O., \& Mandrikin, D. (2018). Innovative development strategy formation of the modern enterprise. Food Industry Economics, 10(2), 75-82. doi: 10.15673/fie.v10i2.963

14. Sedikova, I. O., \& Diachenko, Yu. V. (2018). Zastosuvannia aparatu teorii ihor pid chas vyboru stratehii rozvytku m'iasopererobnykh pidpryiemstv [Application of the game theory apparatus when choosing a meat processing enterprise development strategy]. Skhidna Yevropa: ekonomika, biznes ta upravlinnia [Eastern Europe: Economics, Business and Management], 1, 234-239.

15. Lahodiienko, V. V., Holodoniuk, O. M. \& Milcheva, V. V. (2018). Stratehichni rishennia prosuvannia na rynok innovatsiinoho produktu zi vtorynnoi syrovyny vynorobstva [Strategic solutions for the promotion of innovative product of recycled wine]. Food Industry Economics, 10(3), 41-47.

16. Aheieva, I. M., \& Aharkova, O. V. (2018). Planuvannia rozvytku pidpryiemstva na osnovi rozrobky stratehichnoho naboru [Enterprise development planning based on strategic set development]. Food Industry Economics, 10(2), 60-68. doi: 10.15673/fie.v10i2.961

17. Lahodiienko, V. V. \& Lahodiienko, N. V. (2019). Modeliuvannia otsinky innovatsiinoi spromozhnosti promyslovykh pidpryiemstv [Modeling the assessment of innovative capacity of industrial enterprises]. Financial and credit activity-problems of theory and practice. 28(1), 280-289. doi: 10.18371/fcaptp.v1i28.162979

18. Kalaman, O., Okulicz-Kozaryn, W., \& Purtskhvanidze, O. (2019). Risk as a specific component of strategic enterprises management in the agrarian sector in the current conditions of Ukraine development. Food Industry Economics, 11(2), 54-61. doi: 10.15673/fie.v11i2.1395

19. Lahodiienko, V. V. (2014). Orhanizatsiia marketynhovoi diialnosti v ahrarnykh pidpryiemstvakh [Organization of marketing activities in agricultural enterprises]. Ekonomichnyi analiz [Economic analysis], 18(3), 56-59.

20. Ford, H. (2015). Moie zhyttia ta robota [My life and work]. K.: Nash Format.

21. Porter, M. E. (1985). Competitive Advantage. New York: Academy of Management.

22. Sedikova, I. (2019). Development of conceptual principles of the circular economy. Food Industry Economics, 11(2), 47-53. doi: 10.15673/fie.v11i2.1394

23. Ansoff, I. (1999). Nova korporatyvna stratehiia [New corporate strategy]. SPb .: Piter Kom.

24. Porter, M. (1997). Stratehiia konkurentsii [Competition strategy]. K.: Osnovy.

25. Khemel, H., Prakhalad, K., \& Tomas, H. (2005). Stratehichna hnuchkist [Strategic flexibility]. SPb: Piter.

26. Pastukhova, V. V. (2002). Stratehichne upravlinnia pidpryiemstvom v umovakh nestabilnosti zovnishnoho seredovyshcha [Strategic management of the enterprise in conditions of instability of the environment]. K.: KNTEU.

Received 9 July 2019

Approved 23 July 2019

Available in Internet 16.10.2019

Каламан О.Б.

кандидат экономических наук, доцент кафедра менеджмента и логистики E-mail: kalaman.olga@gmail.com ORCID ID: 0000-0001-5586-7654

\section{Долинская Е.А.}

доктор экономических наук, профессор кафедра менеджмента и логистики E-mail: kaf-ml@gmail.com

ORCID ID: 0000-0008-5217-1478

кафедра маркетинга, предпринимательства и торговли

Одесская национальная академия пищевых технологий

ул. Канатная, 112, г. Одесса, Украина, 65039

E-mail: dolinskaya_alena@ukr.net

\section{КОНЦЕПТУАЛЬНЫЕ ПОЗИЦИИ ФУНКЦИОНИРОВАНИЯ СТРАТЕГИИ ПРЕДПРИЯТИЯ}

Обеспечение эффрективного развития производственных предприятий требует проведения ряда мероприятий, которые направлены на планирование и систематическую организацию его дея- 
тельности, принимая и осуществляя реализацию управленческих решений, проведения производственных и инновационных процессов и оценку достигнутых результатов на основе участия внутренних и внешних стратегических импульсов. Комплексным организационно-экономическим мероприятием, которое обеспечивает долгосрочное развитие предприятия, является разработка и реализация стратегий. Существует большое разнообразие мнений относительно категории «стратегия» и целесообразности ее применения в экономических исследованиях.

В статье проведен анализ понятия стратегии, ее структуры и выполняемых ею функций. Отдельного внимания заслуживает понятие роли стратегии в жизни предприятия. По мнению автора, стратегия - это целенаправленный план, действующий на управленческий объект в долгосрочной перспективе, что имеет свой обобщенный характер и основан на определенной концепции, программе и действиях для достижения поставленных целей и выполнения миссии организаций.

В свою очередь, указано, что стратегия развития производственного предприятия - это общий план действий по организации и обеспечению его развития в долгосрочной перспективе, основанный на концепции его стратегического развития, учитывающий принципы стратегического развития предприятия и определенный в соответствии с процессом стратегического развития для осуществления производственной деятельности и реализации нововведений с учетом имеющихся потенциала и ресурсов, и достижения поставленных целей.

Выявлено, что задача стратегического планирования деятельности предприятия - одна из важных в условиях конкуренции. К ее решения реальные предприятия оказались неподготовленными. Для понимания данного процесса необходимо раскрытие содержания стратегического подхода в управлении предприятием. Основная задача данной статьи - определить требования к разработке и реализации стратегии, вытекающие из результатов теоретического анализа внутренней и внешней среды функционирования предприятия. При фрормировании основной стратегии предприятия его важно не потеряться в бесконечности несопоставимых выборов и свести их к дискретному множеству вариантов. Разработка и изложение рекомендаций по проведению этой необходимой части разработки и реализации стратегии - вторая задача данной статьи.

Ключевые слова: стратегия предприятия, система стратегического управления, стратегические решения, политика предприятия, разделы стратегии, стратегическое планирование, роль стратегии.

Каламан О.Б

кандидат економічних наук, доцент кафедра менеджменту і логістики E-mail: kalaman.olga@ gmail.com ORCID ID: 0000-0001-5586-7654
Савенко I.I.

доктор економічних наук, профресор кафедра менеджменту і логістики

E-mail: kaf-ml@gmail.com

ORCID ID: 0000-0008-5217-1478

\section{Долинська 0.0 .}

кафедра маркетингу, підприємництва і торгівлі

Одеська національна академія харчових технологій вул. Канатна, 112, м. Одеса, Україна, 65039

E-mail: dolinskaya_alena@ukr.net

\section{КОНЦЕПТУАЛЬНІ ПОЗИЦІЇ ФУНКЦІОНУВАННЯ СТРАТЕГІЇ ПІДПРИЄМСТВА}

Забезпечення ефективного розвитку виробничих підприємств вимагає проведення ряду заходів, що займаються плануванням та систематичною організацією його діяльності, приймаючи та здійснюючи реалізацію управлінських рішень, проведення виробничих та інноваційних процесів та оцінювання досягнутих результатів на основі участі внутрішніх та зовнішніх стратегічних імпульсів. Комплексним організаційно-економічним заходом, що забезпечує довгостроковий розвиток підприємства, $є$ розробка та реалізація стратегій. Існує велика різноманітність думок відносно категорії «стратегія» та доцільності її застосування в економічних дослідженнях.

В статті проведено аналіз поняття стратегії, її структури та виконуваних нею функцій. На окрему увагу заслуговує поняття ролі стратегії в житті підприємства. На думку автора, стратегія - це цілеспрямований план, що діє за управлінським об'єктом в довгостроковій перспективі, що має свій узагальнений характер і заснований на визначеній концепції, програмі і діях для досягнення поставлених цілей і виконання місії організацій.

В свою чергу, зазначено, що стратегія розвитку виробничого підприємства - це загальний план дій з організації та забезпечення його розвитку в довгостроковій перспективі, заснований на концепції 
його стратегічного розвитку, що враховує принципи стратегічного розвитку підприємства і певний відповідно до процесу стратегічного розвитку для здійснення виробничої діяльності та реалізації нововведень з урахуванням наявних потенціалу і ресурсів, і досягнення поставлених цілей.

Виявлено, що задача стратегічного планування діяльності та розвитку підприємства - одна 3 важливих в умовах конкуренції. До її вирішення багато реальних підприємств опинилися не підготовленими. Для розуміння даного процесу необхідне розкриття змісту стратегічного підходу в теорії підприємства і в практиці управління підприємствами. Основне завдання даної статті - визначити вимоги до розробки і реалізації стратегії, що випливають з результатів теоретичного аналізу внутрішнього і зовнішнього середовища функціонування підприємства. При формуванні стратегії підприємства важливо не загубитися в безмежності непорівнянних між собою можливостей стратегічного вибору, звести різноманіття цих можливостей в кожному напрямі діяльності підприємства до дискретної безлічі варіантів. Розробка і виклад рекомендацій щодо проведення цієї необхідної частини розробки і реалізації стратегії - друге завдання даної статті.

Ключові слова: стратегія підприємства, система стратегічного управління, стратегічні рішення, політика підприємства, розділи стратегії, стратегічне планування, роль стратегії.

\section{Література}

1. Градов О.П. Економічна стратегія фірми: підручник. СПб: Фахова література, 1995. 414 с.

2. Економічна стратегія фірми: навч. посіб. / О. П. Градов та ін. СПб: Фахова література, 2003. 958 с.

3. Stupnytska T., Kalaman O., Markova T. Ensuring of the enterprise operation effacacy: Management aspect // Periodicals of Engineering and Natural Sciences. 2019. Issue 7, № 2. P. 534-545.

4. Managing the Competitiveness of the Enterprise in the Context of Transformational Change / N. Kuprina and other // International Journal of Recent Technology and Engineering. 2019. Issue 8, № 2. P. 4909-4914. doi: 10.35940/ijrte.B3706.078219

5. Томпсон А. А., Стрікленд А. Д. Стратегічний менеджмент: концепції і ситуації для аналізу. М: Вільямс, 2006. 928 c.

6. Wright P. L., Pringle C. D., Kroll M. J. Strategic management: text and cases,. Boston: Allyn and Bacon, 1992. 969 c.

7. Mockler R. J. Strategic Management: An Integrative Context-Specific Process. Harrisburg-London: Idea Group Publishing, 1992. $246 \mathrm{c}$.

8. Сфремов В. С. Стратегія бізнесу: концепції і методи планування. М.: Фінпресс, 1998. $191 \mathrm{c.}$

9. Мінцберг Г., Альстренд Б., Лемпел Д. Школи стратегій / Мінцберг Г., Альстренд Б., Лемпел Д.; пер.с англ. Ю.Каптуревський, Д.Раевська, Л.Царук. СПб: Пітер, 2000. 336 с.

10. Strategically-Oriented Enterprise Management through Information Systems / O. Zybareva and other // International Journal of Recent Technology and Engineering. 2019. Issue 8, № 2. P. 3014-3017. doi: 10.35940/ijrte.B2900.078219

11. Comparison of Methods For Determining The Competitiveness of Enterprises To Determine MarketStrategy / S.Bondarenko and other // International Journal of Civil Engineering and Technology. 2018. Issue 13, № 9. P. 890-898.

12. Агеєва I.M., Агаркова О.В. Дослідження підходів до формування стратегічних напрямів розвитку підприємств Південного регіону // Економічні та соціальні аспекти розвитку України на початку XXI століття: матеріали VI Міжнар. наук.-практ. конф., Одеса, 11-13 жовт. 2018 р. / ОНАХТ. Одеса, 2018. С. 65-67.

13. Kalaman O., O. Volodina, Mandrikin D. Innovative development strategy formation of the modern enterprise // Food Industry Economics. 2018. Vol.10, Issue 2. P. 75-82. doi: 10.15673/fie.v10i2.963

14. Седікова I. О., Дьяченко Ю. В. Застосування апарату теорії ігор під час вибору стратегії розвитку м’ясопереробних підприємств // Східна Європа: економіка, бізнес та управління. 2018. №1. С. $234-239$.

15. Лагодієнко В.В., Голодонюк О.М., Мільчева В.В. Стратегічні рішення просування на ринок інноваційного продукту зі вторинної сировини виноробства // Економіка харчової промисловості. 2018. Т. 10, Вип. 3. C. 41-47. doi: 10.15673/fie.v10i3.1060

16. Агеєва I. М., Агаркова О.В. Планування розвитку підприємства на основі розробки стратегічного набору // Економіка харчової промисловості. 2018. Т. 10, Вип. 2. С. 60-68. doi: 10.15673/fie.v10i2.961

17. Лагодієнко В.В., Лагодієнко Н.В. Моделювання оцінки інноваційної спроможності промислових підприємств // Financial and credit activity-problems of theory and practice. 2019. Issue 28. Vol.1. P. 280-289.

18. Kalaman O., Okulicz-Kozaryn W., Purtskhvanidze O. Risk as a specific component of strategic enterprises management in the agrarian sector in the current conditions of Ukraine development // Food Industry Economics. 2019. Vol.11, Issue 2. P. 54-61. doi: 10.15673/fie.v11i2.1395

19. Лагодієнко В. В. Організація маркетингової діяльності в аграрних підприємствах // Економічний аналіз. 2014. Т. 18(3). С. 56-59.

20. Форд Генрі. Моє життя та робота / Пер. з англійської Уляни Джаман. К.: Наш Формат, 2015. 384 с.

21. Porter M. E. Competitive Advantage. New York: Academy of Management, 1985. 658 p. 
22. Sedikova I. Development of conceptual principles of the circular economy // Food Industry Economics. 2019. Vol.11, Issue 2. P. 47-53. doi: 10.15673/fie.v11i2.1394

23. Ансофф I. Нова корпоративна стратегія / Ансофф I.; пер. з англ. С.Жильцов. СПб.: Пітер Ком, 1999. $416 \mathrm{c}$. $1997.390 \mathrm{c}$

24. Портер М. Стратегія конкуренції / Портер М.; пер. з англ. А. Олійник, Р. Скільського. К.: Основи,

25. Хемел Г., Прахалад К., Томас Г. Стратегічна гнучкість / Хемел Г., Прахалад К., Томас Г.; пер. 3 англ. СПб: Пітер, 2005. 381 с.

26. Пастухова В.В. Стратегічне управління підприємством в умовах нестабільності зовнішнього середовища: дис. ... доктора екон. наук: 08.06.01 : захист 25.06.2003 / наук. конс. Мазаракі А.А. К.: КНТЕУ, 2002. $301 \mathrm{c}$.

Стаття надійшла 9.07.2019

Стаття прийнята до друку 23.07.2019

Доступно в мережі Internet 16.10.2019

Цитування згідно ДСТУ 8302:2015

Kalaman O., Savenko I., Dolynska O. Conceptual positions of enterprise strategy functioning // Food Industry Economics. 2019. Vol.11, Issue 3. P. 50-58. doi: 10.15673/fie.v11i3.1461

Cite as APA style citation

Kalaman, O., Savenko, I., \& Dolynska, O. (2019). Conceptual positions of enterprise strategy functioning. Food Industry Economics, 11(3), 50-58. doi: 10.15673/fie.v11i3.1461 